\title{
Between a chicken and a grape: estimating the number of human genes
}

\author{
Mihaela Pertea ${ }^{1}$, Steven L Salzberg ${ }^{2^{*}}$ \\ From Beyond the Genome: The true gene count, human evolution and disease genomics \\ Boston, MA, USA. 11-13 October 2010
}

Ever since the discovery of the genetic code, scientists have been trying to catalog all the genes in the human genome. Over the years, the best estimate of the number of human genes has grown steadily smaller, but we still do not have an accurate count. Many expected this question to be resolved with the publication of the human genome sequence in 2001, but estimates have continued to fluctuate since then, moving both up and down. Comparisons with other species show that nothing about the human gene count is exceptional, and it is not particularly different from other mammalian species. In this talk, I will review the history of efforts to establish the human gene count and explain the evidence behind the current best estimate of 22,333 genes.

\section{Author details}

${ }^{1}$ Center for Bioinformatics and Computational Biology, University of

Maryland, College Park, MD 20742, USA. ${ }^{2}$ Department of Computer Science,

University of Maryland, College Park, MD 20742, USA.

Published: 11 October 2010

doi:10.1186/gb-2010-11-S1-I1

Cite this article as: Pertea and Salzberg: Between a chicken and a grape: estimating the number of human genes. Genome Biology 2010

11(Suppl 1):11.
Submit your next manuscript to BioMed Central and take full advantage of:

- Convenient online submission

- Thorough peer review

- No space constraints or color figure charges

- Immediate publication on acceptance

- Inclusion in PubMed, CAS, Scopus and Google Scholar

- Research which is freely available for redistribution

Submit your manuscript at www.biomedcentral.com/submit
BioMed Central 